\title{
Deforestation and malaria incidence in the legal Amazon Region between 1996 and 2012
}

\author{
Desflorestamento e incidência de malária na região da \\ Amazônia Legal entre 1996 e 2012
}

\author{
Raphael Mendonça Guimarães ${ }^{1}$, Bárbara Campos Valente ${ }^{1}$, \\ Priscila Almeida Faria ${ }^{1}$, Lásaro Linhares Stephanelli" ${ }^{1}$, \\ Juliana Valentim Chaiblich ${ }^{1}$, Felipe Bagatoli Silveira Arjona ${ }^{1}$
}

\begin{abstract}
Malaria is a major public health problem, and Brazil is the largest contributor in America to the number of cases. In the country, the Amazon concentrates around $99.5 \%$ of the cases. This article aims to compare trends in deforestation rate and the parasite index of malaria in the Amazon region between 1996 and 2012. The annual crude rate of deforestation and the Annual Parasite Index (API) of malaria between 1996 and 2012 were estimated. The rate of deforestation has great variability among the states every year, and a similar situation is observed for malaria API over the studied period. There are important variations across the states within this period. The historical series of crude deforestation rate and malaria API have markedly similar trends; with a 1-2 years lag between them, suggesting that the occurrence of fluctuations in deforestation numbers impacts malaria numbers in a period immediately following. The mapping of deforested areas and the analysis of temporal series are therefore useful in the analysis of malaria.

Keywords: malaria; environment; Amazon.
\end{abstract}

\section{Resumo}

A malária é um problema de saúde pública, sendo o Brasil, na América, o país que mais contribui com o número de casos. A Amazônia Legal concentra a maioria dos casos, cerca de 99,5\%. O objetivo deste artigo é comparar as tendências da taxa de desflorestamento e o índice parasitário por malária na região da Amazônia Legal entre 1996 e 2012 . Foram estimados a taxa bruta anual de desflorestamento e o Índice Parasitário Anual de Malária entre 1996 e 2012, para a Amazômia Legal e seus estados. Obtiveram-se a série histórica dos dois indicadores e as estatísticas descritivas por ano e por estado. A taxa de desflorestamento apresenta grande variabilidade entre os estados, ano a ano, e situação semelhante é observada para o IPA de malária no período. Há variação importante quando são observados os estados dentro do mesmo período. As séries históricas da taxa bruta de desflorestamento e do IPA de malária apresentam tendências semelhantes, com um lag de 1-2 anos entre elas, sugerindo que as oscilações nos números de desflorestamento impactam os números de malária em período imediatamente posterior. O mapeamento das áreas desflorestadas e a análise de séries temporais, portanto, são úteis na análise da malária.

Palavras-chave: malaria; ambiente; Amazônia.

1 Escola Politécnica de Saúde Joaquim Venâncio, Fundação Oswaldo Cruz - Rio de Janeiro (RJ), Brazil.

Trabalho realizado na Fundação Oswaldo Cruz, Rio de Janeiro (RJ), Brazil.

Endereço para correspondência: Raphael Mendonça Guimarães - Escola Politécnica de Saúde Joaquim Venâncio, Avenida Brasil, 4365, Sala 314 - Manguinhos CEP: 21041-360 - Rio de Janeiro (RJ), Brazil - Email: raphael.guimaraes@fiocruz.br

Fonte de financiamento: nenhuma.

Conflito de interesses: nada a declarar. 


\section{INTRODUCTION}

Legal Amazon was created in 1953 as an area of operation of the Superintendence of the Amazon Economic Recovery Plan (SPVEA). During the 60s, with the emergence of a political plan to promote the region development, the creation of the Superintendence of the Amazon Development (SUDAM) has replaced the SPVEA. Currently, Legal Amazon area covers nine Brazilian states, some of them localized at northern of Brazil (Amazonas, Acre, Rondônia, Roraima, Amapá, Tocantins and Pará), state of Mato Grosso (located in Midwest) and part of the state of Maranhão (Northeast Region). It covers 720 municipalities, with a land area of $5,217,423 \mathrm{~km}^{2}$, corresponding to $61 \%$ of the Brazilian territory ${ }^{1}$.

Amazon rainforest is considered the largest of Brazilian forest biomes, and the world's largest rainforest. About 4 million square kilometers of the Brazilian Amazon were originally covered by forests. However, after years of exploration, only $15 \%$ of the original area remains non-deforested. This deforestation process was accentuated on the last four decades, concentrated in the southern and eastern edges of Amazon; therefore some crop formations are at risk of disappearing, as can be noted in some regions of Pará, Maranhão and Mato Grosso².

Malaria is an infectious disease related to both natural and man-modified environment. Some regions such as Amazon have favorable aspects to reproduction of malaria mosquito vectors (Anopheles mosquitoes), such as hydrography and climate ${ }^{3}$. Anopheles' life period is directly associated to environment: the vectors' life cycle, as well as their reservoirs and hosts that participate of the disease transmission chain, is strongly related to their ecosystems environmental dynamics ${ }^{4}$.

In addition to natural environmental conditions, malaria also depends on human action to take place, as described by some studies that link the disease rise and epidemics to men's entry in the woods, when they expose themselves to diseases usually restricted to the wild ${ }^{3,5,6}$.

Previous researches have indicated an association between deforestation and incidence of malaria in Amazon ${ }^{7}$; however this relationship evolution deserves attention. In this sense, this article aims to compare trends in deforestation rate and parasitic index for malaria in Amazon region between 1996 and 2012.

\section{METHODS}

\section{Study design and data source}

It is an ecological study conducted in municipalities of Legal Amazon region. Data between 1996 and 2012 were collected from the IBGE (deforestation) and SINAN (malaria). SINAN dataset was obtained on 2014 and the IBGE data is from Prodes Project (INPE), which is derived from remote sensing. Some indicators were respectively considered as environmental exposure and outcome in health, as follow:
I. Annual crude deforestation rate

Deforestation rate express the estimated loss of forest cover in territory covered by Legal Amazon, and relationship between deforestation and areas of states from Legal Amazon. Specifically, the annual crude deforestation rate consists of the percentage ratio between the annually deforested area $\left(\mathrm{km}^{2} /\right.$ year $)$ and the whole area, and of each state comprising the Legal Amazon (Rondônia, Acre, Amazonas, Roraima, Pará, Amapá, Tocantins, Maranhão and Mato Grosso).

\section{Annual Parasite Index (API) of malaria}

Expresses the number of positive malaria tests (ICD10 B50-53) per thousand inhabitants in a given geographical area, for the current year. This indicator estimates the risk of malaria. It is useful, therefore, for comparative analysis of circumscribed endemic areas where the population is at risk of malaria, such as Legal Amazon.

\section{Data analysis}

Descriptive statistics were calculated for deforestation indicators (annual crude rate) and malaria (API), according to the State and according to the time series year. In addition, for Legal Amazon data, trend lines were estimated for both indicators, annual count of four years period moving average, in order to smoothing the rates and minimizing data fluctuation. The outcome and independent variables were, respectively, Malaria API, and deforestation rate for the years of time series.

An association between deforestation rate and Malaria API was estimated by relative risk for each year of observation: the relationship between malaria cases and the effect of deforestation was modeled by building a generalized linear model using negative binomial distribution due to the absence of temporal autocorrelation in number of cases. The model adequacy was assessed by autocorrelation test and normality of residues. Finally, based on values from 2012, the lowest value for both indicators in time series, relative risks for each year and their confidence intervals were calculated to observe which year showed statistically significant indicators values.

\section{RESULTS}

The deforestation rate has a great yearly variability among states, which is demonstrated by great interquartile distances and ranges observed every year. It is important to mention that this variability among states has been decreasing every year, especially from 2009 (Figure 1a). A similar situation is observed for malaria API along the study period (Figure 1b). Regarding to intrastate analysis, some states show a wide variability for the period described (e.g., Rondônia, Pará and Mato Grosso) while others show a less obvious variation (e.g., Amazonas, Roraima and Amapá) (Figure 1c). In the same way, overall ranges are 

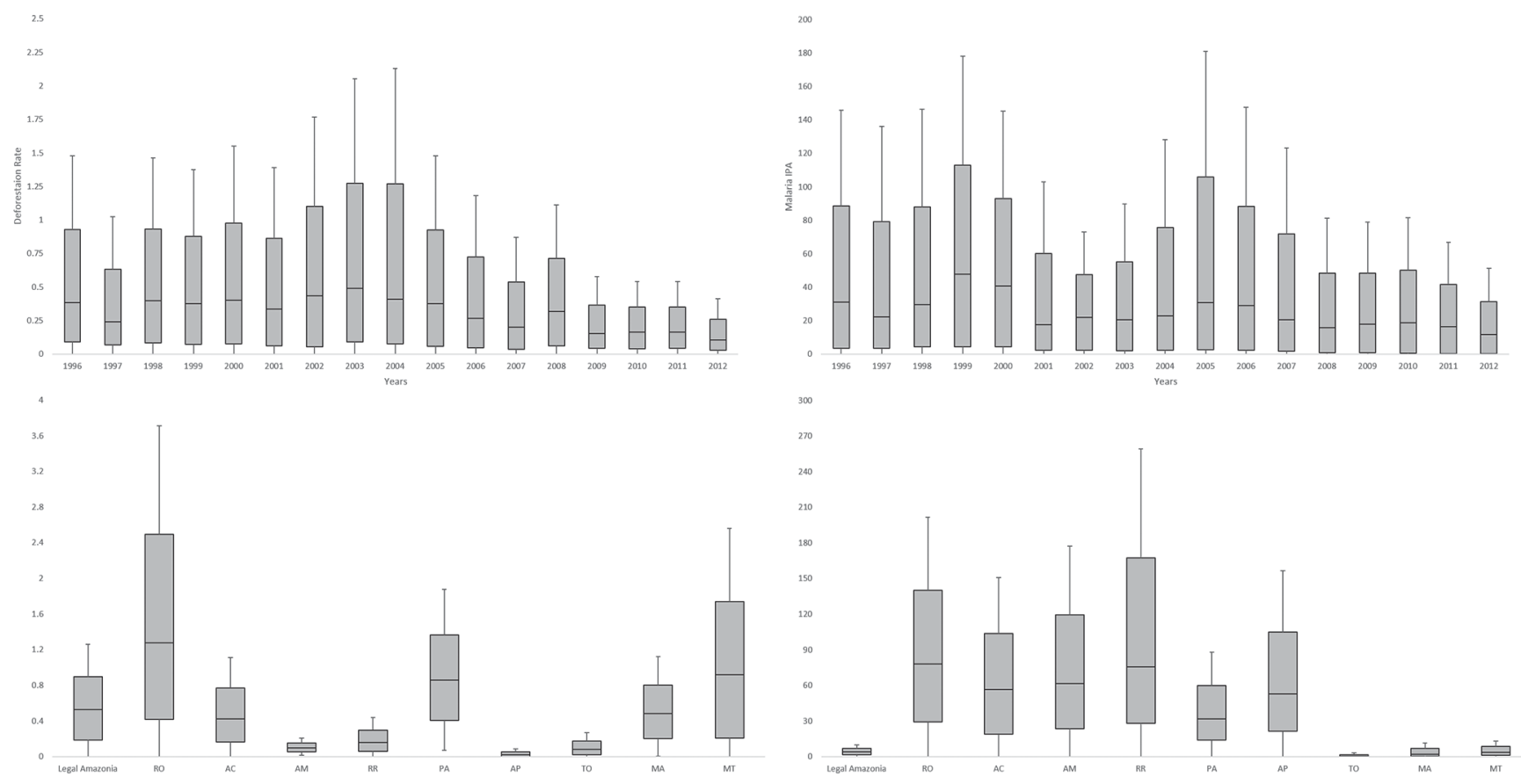

Figure 1. Descriptive statistics of deforestation (annual crude rate) and malaria (API) indicators for a period and the Amazonian states. Brazil, 1996-2012. (a) Deforestation rate for periods of time; (b) Malaria API for Legal Amazonia States; (c) Deforestation for Legal Amazonia States; (d) Malaria API for Legal Amazonia States

notable, except for Tocantins, Maranhão and Mato Grosso (Figure 1d). We observe that these amplitudes are a relative measure; i.e., having a small variation does not mean that deforestation and the incidence of malaria have a low magnitude. The three states with the highest rates of deforestation in early time series (1996) were Rondônia, Mato Grosso and Pará, and, in the last year (2012), the top three states were Rondônia, Acre and Pará. The first three states highest rates of malaria in 1996 were Roraima, Rondônia and Amapá and, in 2012, Acre, Amapá and Rondônia.

Looking at historical series of deforestation and malaria API crude rates, we observed markedly similar trends, with a lag of 1-2 years between them, suggesting that the fluctuations in deforestation numbers affect the malaria numbers in an immediate aftermath (Figure 2a). This assumption becomes clearer when we observe the curves of moving average with both indicators (Figure 2b).

In general, these two indicators tend to decline. There is a peak of deforestation rate in 2004, and, of malaria API in 2005. In fact, the deforestation rate shows significantly higher rates in the period between 1998 and 2005, especially for 2002 to 2005, when calculating relative risk year by year for the two indicators, compared to the year 2012, which was a year of lower rates (Figure 3a). For malaria API, the range with significantly higher rates was from 1998 to 2007, mainly between 2003 and 2006 (Figure 3b).

\section{DISCUSSION}

Malaria's epidemiology has some determining interrelated factors, such as soil use, human behavior, natural environment physical and biological elements and changes caused by human intervention. Amazon exhibits a combination of these factors becoming an ideal local for the cycles of malaria and other endemic diseases, including: the high rates of migration development, urban growing and the deforestation in the last three decades ${ }^{8}$.

The considered environmental issues are related to negative impacts in the region. Through environmental data from Amazon region it is possible to observe a scenario that has attracted the world's attention to the Brazilian Amazon; the allowance of new energy projects, nature reserves exploration and, consequently, increasing deforestation there.

The creation of Protected Areas is a way to safeguard the ecosystems and biodiversity integrity, and also helps to ensure the right to stability for traditional populations living in the area. In 2010, Conservation Units (UC) of Legal Amazon have extensions of $2,197,485 \mathrm{~km}^{2}$, i.e. $43.9 \%$ of the region. Protected areas can be classified by the management degree (federal, state or municipal), as well as the level of consented influence - the 


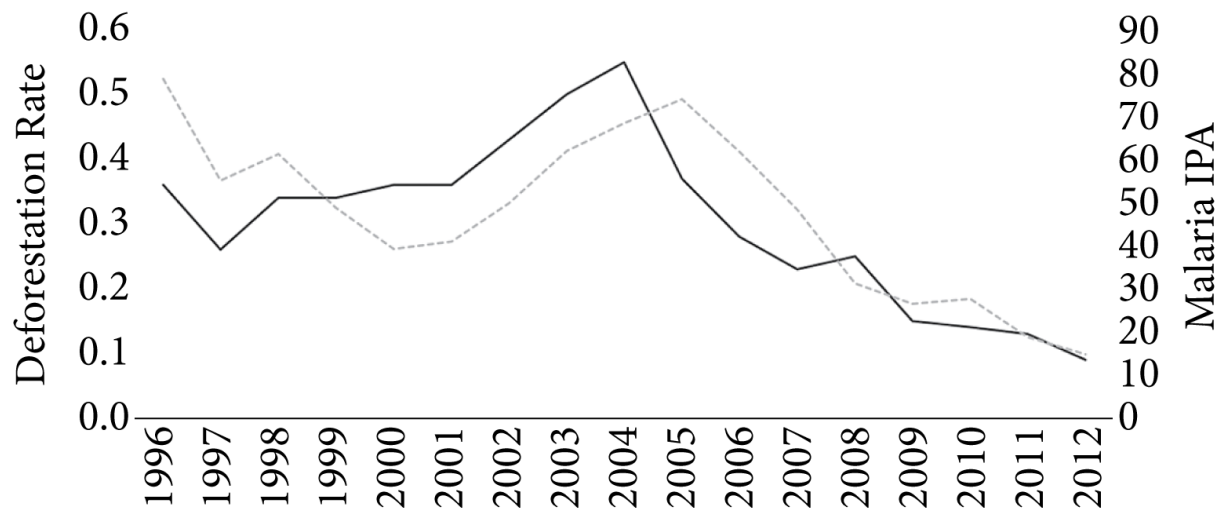

Deforestation Rate -... Malaria IPA

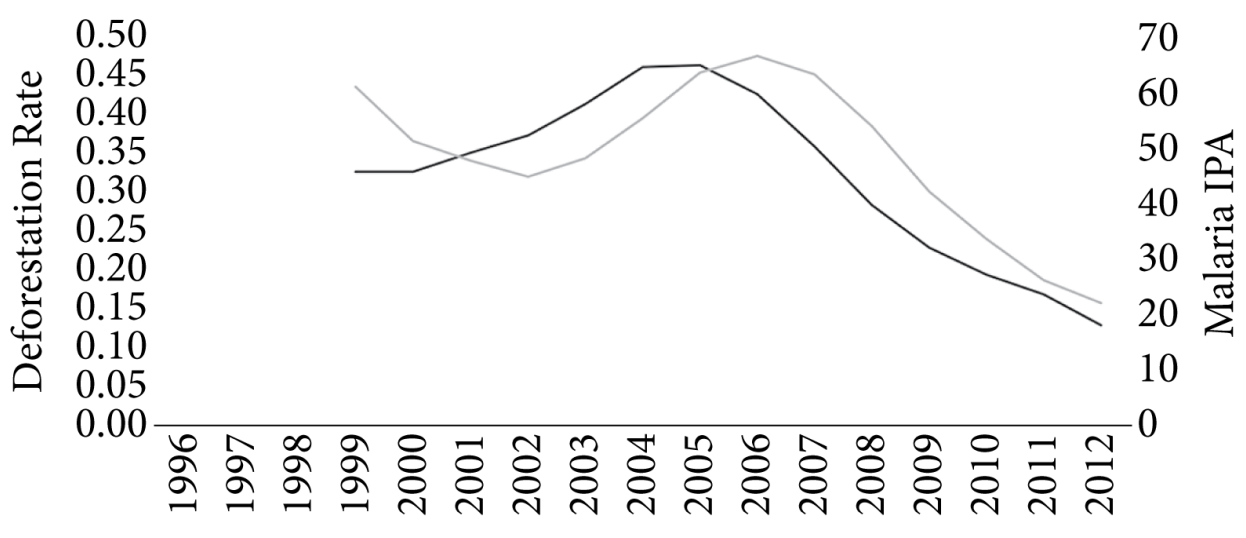

\section{Deforestation Rate — Malaria IPA}

Figure 2. Time series and moving average trend for crude rate of deforestation and Annual Parasite Index Series (API) for malaria in Legal Amazon. Brazil, 1996 to 12. (a) Times series 1996 to 12; (b) Moving average (4 years)

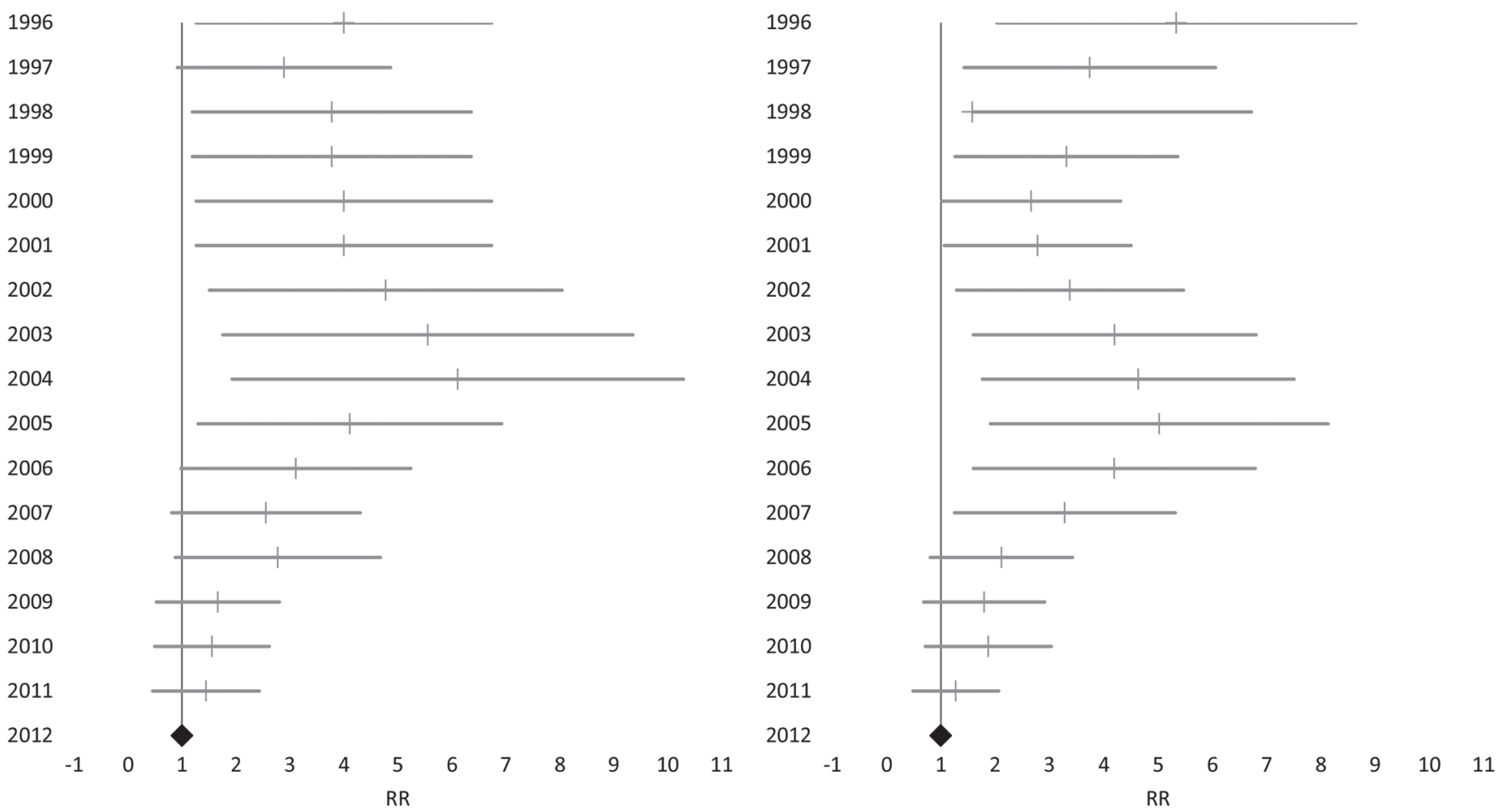

Figure 3. Risk Analysis for deforestation and malaria in the Brazilian Amazon according to year. Brazil, 1996-2012. (a) Deforestation Rate; (b) Malaria API 
Integral Protection and Sustainable Use. The UC Sustainable Use (allows economic activities under management regime from resident communities) had $62.2 \%$ of occupied areas, while Integral Protection had $37.8 \%$.

Impacts on malaria epidemiology are evident; the ecosystem modification with open access and vegetation removal generates a differentiated environmental exposure of population who live in areas of high density of the mosquito. On the other hand, deforestation creates housing areas, increasing local population, thereby aggravating magnitude of malaria in these locations.

According to Tauil et al. ${ }^{10}$, the disease distribution is not random, even if the majority of cases in the country is concentrated in the Amazon region. The focus of malaria is located primarily in certain localities with economic and social development projects, attracting a great, intense and precarious migratory contingent.

Castro and Singer ${ }^{3}$, describe the case of settlement of Machadinho, Rondônia, and point out that the auspicious Amazon environment to spread of malaria is due to climate, rainy seasons, the streams of breeding sites that serve as focus for the mosquito, and type of soil. However, they show that these factors are not sufficient to explain the disease. Yet according to the authors, the initial occupation phase during deforestation is the time of greatest incidence of malaria. The following years - about five years - mark a second phase, when there is a decline of the disease rate, which coincides with socio-economic improvement in colonizers environment. Continuing this improvement, there is a third stage which is associated with decrease of the actions on environment, presenting with low rates.

Similarly, Chimielli and Alves ${ }^{5}$ show human exposure to several infectious diseases, including malaria facing human entry into the forest. Their research is focused on biological hazards of Legal Amazon, especially in cases of Coari-Manaus gas pipeline work, and report the number of deaths occurred over years for works in the region due to epidemics of disease.

Barbieri et al. ${ }^{11}$ points out that malaria's intensity is related to natural and man-made environment, and it's necessary to understand the health-disease process in order to know how the disease specificity and environment use are articulated. Historically, the occupation of endemic areas occurred through the development of digging activities, agricultural colonization and livestock.

Some studies try to explain the relationship between the increased number of cases and deforestation. Vasconcelos et al. ${ }^{6}$ verified the influence of implementation of a dam and increase of number of reported malaria cases in Legal Amazon since the 80 's. There was a proliferation of aquatic plants in wetlands and, according to the authors, these plants have become breeding grounds for mosquitoes, which is related to increase of vectors in the region and flow of people from other cities, who came attracted by the labor market.

In a cohort study performed by Silva-Nunes et al. ${ }^{12}$, in Acre, malaria was strongly associated with deforestation activity and agriculture, and some geographic clusters were observed in recently occupied areas, where conditions for the disease transmission were created, and local populations and even those that just work there became susceptible to the disease.

In a retrospective study, Parente ${ }^{13}$ analyzed the occurrence of malaria in four municipalities of Pará and the relationship with deforestation on the period between 1988 and 2005. The authors concluded that highest deforestation rates, with records above 6,000 square kilometers in 1988, 1995, 1996, 2000 and 2002 to 2004, are followed by significant increase in malaria incidence, suggesting a relationship between increased deforestation and increased disease rate.

Saraiva et al. ${ }^{14}$ examined the relationship between urban expansion and malaria in Manaus, state of Amazonas. The study found that after 13 years without autochthony record, areas that suffered human activities such as deforestation and urban expansion, contributed to epidemic profile of malaria, mainly because the population of rural area was attracted to urban areas in jobs search, abandoning their land and creating the so called slums.

Finally, a study of Moraes et al. ${ }^{15}$ found that some factors for occurrence of malaria, as volume of rainfall in some municipalities in Pará, were not decisive for increasing the number of cases, but yet the unstructured growing of these municipalities over the forest and practice of deforestation.

With the implementation of Intensification Plan of Actions for Malaria Control (PIACM) in 2000, malaria API decreased compared to previous years in the region. Even with this reduction, the disease incidence remains high. In the period between 1999 and 2001, reduction was not uniform in all states of Amazon region. There was a percentage decline in the state of Amazonas, with $71 \%$ and Acre with $67 \%$ (highest percentage), contrasting with Rondônia (9\%) and Amapá (15\%), the worst states compared to the incidence drop in this period ${ }^{16}$. In fact, we observed a decrease in malaria API throughout the region. As an example, there is a reduction of up to $58 \%$ in number of malaria cases and 36\% in number of disease relapses between 2008 and 2012 in Rondônia, a related trend mainly to improvements in economy, development of local health system and desforestment reduction ${ }^{17}$. This relationship between the states corroborates with the analysis described in this study.

Finally, Vasconcelos et al. ${ }^{6}$ proposed in their research using remote sensing, to compare the environmental changes to the distribution of malaria in the Amazon. The authors emphasize the influence of deforestation in epidemics because, although reducing moisture, deforestation increases the temperature. 
That would be the most worrying factor, since vectors are very adaptable and the region has other water sources (rivers, dams) for its reproduction. Valle and Lima ${ }^{18}$ assessed the incidence of malaria cases between 2004 and 2008 in six states of the legal Amazon and characterized the spatial patterns, confirming that remote sensing can be a useful tool for surveillance of malaria, especially when combined with other techniques analysis such as clustering of municipalities according to other environmental features.

As the study limitation, the Annual Parasite Index or Annual Parasite (API) is considered an indicator of the risk of malaria transmission and is used to classify areas into low, medium and high risk of transmission. As an estimate of the disease incidence in the population, it consists of the count of positive tests instead of cases.

\section{REFERENCES}

1. Instituto Brasileiro de Geografia e Estatística. Amazônia legal [Internet]. Rio de Janeiro [cited 2015 june 15]. Available from: http://www.ibge.gov. $\mathrm{br} /$ home/geociencias/geografia/amazonialegal.shtm? $\mathrm{c}=2$

2. Instituto Brasileiro de Geografia e Estatística. Indicadores de Desenvolvimento Sustentável. Brasil 2010. Rio de Janeiro: IBGE; 2010. (Estudos e Pesquisas Informação Geográfica, 7).

3. Castro MC, Singer BH. Meio ambiente e saúde: metodologia para análise espacial da ocorrência de malária em projetos de assentamento. Rev Bras Estud Popul. 2007;24(2):247-62. http://dx.doi.org/10.1590/S010230982007000200005 .

4. Barcellos C, Monteiro AMV, Corvalán C, Gurgel HC, Carvalho MS, Artaxo P, et al. Mudanças climáticas e ambientais e as doenças infecciosas: cenários e incertezas para o Brasil. Epidemiol. Serv. Saúde. 2009;18(3):285-304.

5. Chimelli MAR, Alves GB. Exposição dos riscos biológicos na floresta amazônica. Revista da Associação Brasileira dos Higienistas Ocupacionais. 2009;19:18-21.

6. Vasconcelos $\mathrm{CHH}$, Novo EM, Donalisio MR. Use of remote sensing to study the influence of environmental changes on malaria distribution in the Brazilian Amazon. Cad Saude Publica. 2006;22(3):517-26. http://dx.doi. org/10.1590/S0102-311X2006000300006. PMid:16583095.

7. Hahn MB, Gangnon RE, Barcellos C, Asner GP, Patz JA. Influence of deforestation, logging, and fire on malaria in the Brazilian Amazon. PLoS One. 2014;9(1):e85725. http://dx.doi.org/10.1371/journal.pone.0085725. PMid:24404206.

8. Confalonieri UE. Saúde na Amazônia: um modelo conceitual para a análise de paisagens e doenças. Estud. Av.. 2005;19(53):221-36. http://dx.doi. org/10.1590/S0103-40142005000100014.

9. Veríssimo A, Rolla A, Vedoveto M, Futada SM. Áreas protegidas na Amazônia brasileira: avanços e desafios. Belém: Imazon; São Paulo: Instituto Socioambiental, 2011

10. Tauil P, Deane L., Sabroza P, Ribeiro C. A malária no Brasil. Cad Saúde Pública. 1985;1(1):71-111.

\section{CONCLUSION}

This brief analysis described time series of deforestation and incidence of malaria in Legal Amazon. While previous studies have found results that suggested a link between these two events, we assessed their temporal relationship through the analysis performed. The choice of statistical model allowed observation of this relationship, regarding to a long enough time series to observe effects.

Considering that the risk of contracting malaria is related to environmental changes caused by human activities, deforestation is a major factor in maintaining the disease cycle. It is, therefore, necessary to consider the mapping of areas suffering deforestation in order to control the vector and organize the health services as they will receive a higher demand for preventive and diagnostic measures of disease.

11. Barbieri AF, Soares Fo B, Coelho L. Uso da terra e malária: uma análise espacializada para o Norte de Mato Grosso 1992 a 1995 [Internet]. Rio de Janeiro: ABEP; 2000 [cited 2015 june 16]. Disponível em: http://www. abep.nepo.unicamp.br/docs/anais/pdf/2000/Todos/ambt15_1.pdf

12. Silva-Nunes M, Codeço CT, Malafronte RS, Silva NS, Juncansen C, Muniz PT, et al. Malaria on the Amazonian frontier: transmission dynamics, risk factors, spatial distribution, and prospects for control. Am J Trop Med Hyg. 2008;79(4):624-35. PMid:18840755.

13. Parente AT. Incidência de malária no estado do Pará e suas relações com a variabilidade climática regional [dissertation]. Belém: Instituto de Geociência, Universidade Federal do Pará; 2007.

14. Saraiva M, Amorim RD, Moura MA, Martinez-Espinosa FE, Barbosa M. Expansão urbana e distribuição espacial da malária no município de Manaus, Estado do Amazonas. Rev Soc Bras Med Trop. 2009;42(5):515-22. http://dx.doi.org/10.1590/S0037-86822009000500008. PMid:19967233.

15. Moraes BC, Costa JMN, Costa ACL, Costa MH. Variação espacial e temporal da precipitação no estado do Pará. Acta Amazon. 2005;35(2):207-14. http:// dx.doi.org/10.1590/S0044-59672005000200010

16. Brasil. Ministério da Saúde. Secretaria de Vigilância em Saúde. Programa Nacional de Prevenção e Controle da Malária PNCM. Brasília: Ministério da Saúde; 2003.

17. Vieira GD, Gim KN, Zaqueo GM, Alves TC, Katsuragawa TH, Basano $\mathrm{SA}$, et al. Reduction of incidence and relapse or recrudescence cases of malaria in the western region of the Brazilian Amazon. J Infect Dev Ctries. 2014;8(9):1181-7. PMid:25212083.

18. Valle D, Lima JM. Large-scale drivers of malaria and priority areas for prevention and control in the Brazilian Amazon region using a novel multi-pathogen geospatial model. Malar J. 2014;13(1):443. http://dx.doi. org/10.1186/1475-2875-13-443. PMid:25412882.

Recebido em: Jun. 24, 2015 Aprovado em: Ago. 25, 2015 